\title{
The Dolerites of Cross River State (DCRS): Physical and Mechanical Properties
}

\author{
Oden Michael I ${ }^{1}$, Udinmwen Efosa ${ }^{1}$ \& Esu Esu O. ${ }^{1}$ \\ ${ }^{1}$ Department of Geology, University of Calabar, Calabar, Nigeria \\ Correspondence: Udinmwen Efosa, Department of Geology, University of Calabar, Calabar, Nigeria. E-mail: \\ udinmwenefosa@gmail.com
}

Received: October 24, 2012 Accepted: January 17, 2013 Online Published: January 30, 2013

doi:10.5539/enrr.v3n1p135

URL: http://dx.doi.org/10.5539/enrr.v3n1p135

\begin{abstract}
Dolerite occurs in appreciable quantity in Cross River State and these have been locally quarried for construction without proper evaluation of its suitability as construction stones. The physical and mechanical properties as well as the general mineralogy were analyzed in this work to determine the suitability of these dolerites as construction aggregate. Results shows that uniaxial compressive strength (UCS) ranges from $34.2 \mathrm{~N} / \mathrm{mm}^{2}$ to 56 $\mathrm{N} / \mathrm{mm}^{2}$, durability $96.9 \%$ to $99.21 \%$, specific gravity (SG) 2.46 to 3 , water absorption $0.14 \%$ to $1.59 \%$ with an average porosity of 1.19 . The medium/strong compressive strength, low porosity and water absorption, average density and specific gravity and high durability makes it suitable for construction but the presence of plagioclase and pyroxene which sometimes alters to clays and chlorite causing swelling when wet and shrinking when dry is a major limitation. Thus these dolerites without proper treatment/stabilization are not suitable for industrial/heavy traffic construction but can be readily and effectively applied in concrete for light foundation loads and buildings. Results also show that these dolerite are hard, tough, compact and durable and can replace the more expensive/competent construction stones (granite and /or gneiss) for light construction works, however the environmental conditions within which it would be applied should be evaluated and the first few meters around a dolerite sill or dyke should be avoided during quarrying for construction stones as the more softer rocks are found there.
\end{abstract}

Keywords: dolerite, compressive strength, Massif, Oban, Obudu

\section{Introduction}

Dolerites occurs in appreciable quantity in Cross River State but they are minor intrusive when compared with the more competent basement granite/gneiss. The area within the longitudes $8^{\circ} 00^{\prime} \mathrm{E}$ to $9^{\circ} 12^{\prime} \mathrm{E}$ and the latitudes $5^{\circ} 35^{\prime} \mathrm{N}$ to $6^{\circ} 40^{\prime} \mathrm{N}$ covers three major geological terrains in Cross River State, southeastern Nigeria (Oban Massif, Ikom-Mamfe embayment and Obudu plateau).

Dolerite is found in appreciable quantity in all these geological terrains of Cross River State and these intrusions are not controlled by geology i.e. they occur both in the basement and sedimentary terrains. As industrialization and urbanization/development continues, the demands for crushed rocks as construction materials in Cross River State and elsewhere in Nigeria has led to the establishment of many granite quarries by investors for the production of rock aggregate (Amah et al., 2012). These granites/gneisses (commonly used construction stones) though available are expensive due to high demands thus forcing the local community to strictly adhere to the easily quarried dolerite for all forms of construction without proper evaluation of its suitability in such constructions. Thus this paper provides useful information on the physical and mechanical properties as well as the basic mineralogy of dolerite in Cross River State for the suitability of this rock as building/construction stones.

Local commercial quarrying of dolerite in Cross River State started in the early part of the $20^{\text {th }}$ century and they are basically used as aggregates in concrete for foundation loads and buildings. Little or no research has been done on the physical and mechanical properties of the dolerites of Cross River State probably because they are minor intrusive. However, some publications on the geochemistry and petrology of these dolerites are available (Hossain, 1981; Ekwueme, 1994). 


\section{General Geology}

The study area covers the Oban Massif, Ikom-Mamfe embayment and Obudu plateau (Figure 1) southeastern Nigeria with a humid tropical environment which experiences alternation of wet and dry seasons. The Oban Massif is composed of Precambrian basement, which is overlain by Cretaceous-Tertiary sediments of the Calabar Flank. It has an interesting geology which includes metamorphic rocks such as phyllites, schist, gneiss, amphibolites and charnockites with igneous intrusions such as dolerite, granite, granodiorite, diorite, tonalite and monzonite. The most prominent fracture set in Oban Massif is the NNW-SSE, with a trend of $150^{\circ}-160^{\circ}$ from the north. Others are NNE-SSW, E-W and NW-SE sets (Oden et al., 2012).

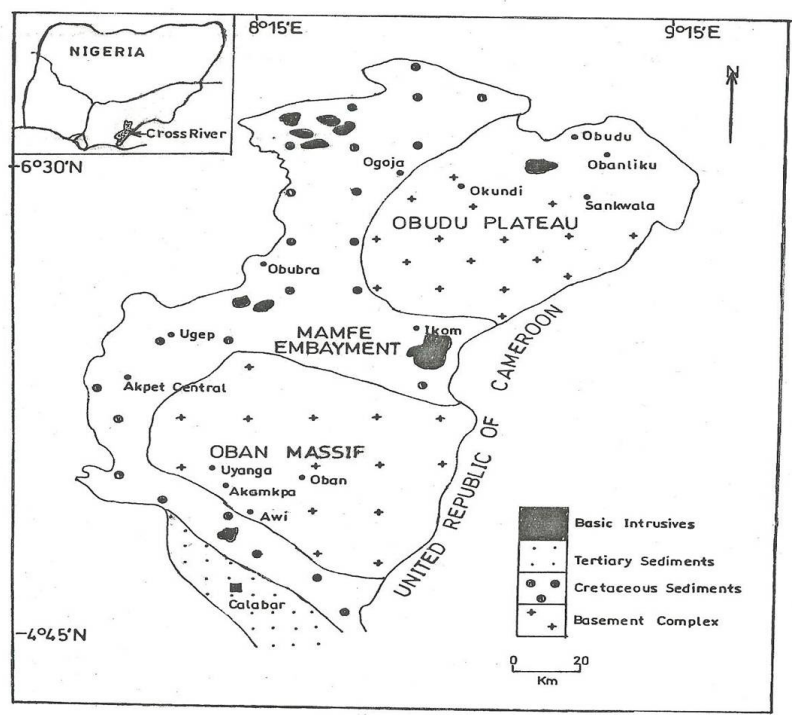

Figure 1. Geologic map of Cross River State showing the basement areas (Oban and Obudu Massifs) and the sedimentary area (Ikom-Mamfe Embayment). Insert is the map of Nigeria. (After Oden et al., 2012)

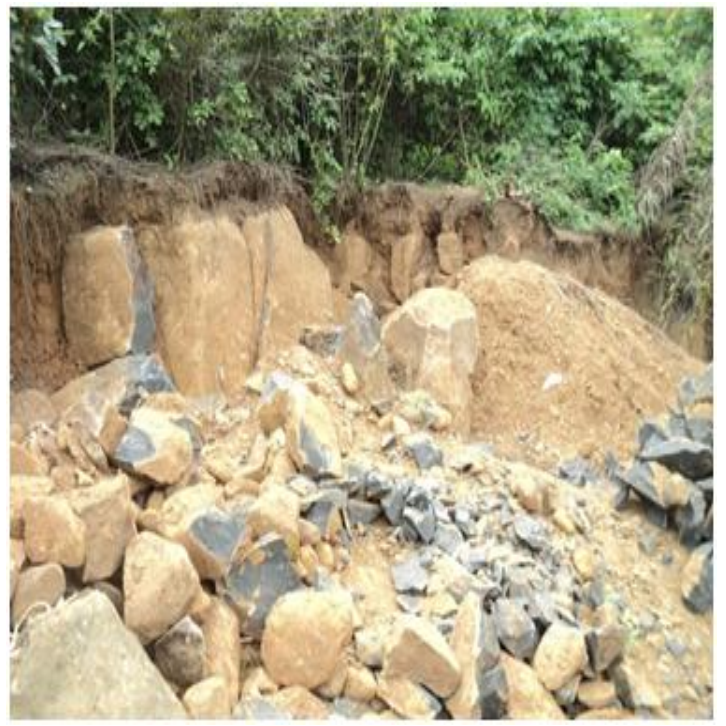

Figure 2. Dolerite sill and aggregate in Ekori (Southeastern Nigeria)

The Ikom-Mamfe embayment is a $130 \mathrm{Km}$ long by $60 \mathrm{Km}$ wide Cretaceous sedimentary basin extending east from the Lower Benue Trough, Nigeria, into Cameroon where it narrows and terminates beneath the Tertiary to Recent volcanic cover of the Cameroon volcanic line (Fairhead et al., 1991). It resulted from the rotation of the Obudu basement with respect to the Oban Massif (Oden et al., 2012), and is predominantly a sedimentary environment in which Albian sandstones and limestones are overlain by a sequence of Lower Turonian sandstones, shales and limestones, all of these being intruded by a series of post- Turonian basic to intermediate intrusive (Hossain, 1981).

The Obudu plateau consists dominantly of basement migmatitic gneisses, schists and a few amphibolites, all of which have been intruded by acidic, basic and ultrabasic igneous rocks (Ephraim, 2012). This area has a rugged topography with a series of elevated ridges separated by lowlands. Structural data (Oden et al., 2012), show that the most prominent fracture set in Obudu basement area is the NW-SE which trends $140^{\circ}-150^{\circ}$ from north. Minor sets occur in the NNE-SSW, E-W and ESE-WNW directions.

\section{Materials and Methods}

A total of thirty (30) dolerite samples were collected from fourteen (14) localities within three major geological terrains in Cross River State (see Table 1). Samples from the Oban Massif were collected at Agoi-Ibami (AI) where the dykes were found intruding Pre-Cambrian basement. Ikom-Mamfe embayment samples were collected from Ugep (UG), Ekori (E), Adim (AD), Agwagune (AG), Ohana (OH), Mkpani (MK), Obubra (OB) and Usumutong (US), where they were all found to intrude the Cretaceous sediments of the embayment as sills, and are overlain with sediments not greater than $1 \mathrm{~m}$ thick on the average (Figure 2). 
Table 1. Locations and description of dolerites from study areas

\begin{tabular}{|c|c|c|c|c|c|}
\hline$\overline{\mathrm{S} / \mathrm{N}}$ & LOCATION & DESIGNATION & AGE & OCCURRENCE & DESCRIPTION \\
\hline$\overline{1}$ & Ugep & UG-1 & Santonian & Sill & Black colour, fine to medium grain \\
\hline 2 & & UG-2 & Santonian & Sill & Black colour, fine to medium grain \\
\hline 3 & Ekori & E-1 & Santonian & Hypabyssal sill & Black colour, fine to medium grain \\
\hline 4 & & E-2 & Santonian & Hypabyssal sill & Black colour, fine to medium grain \\
\hline 5 & & E-3 & Santonian & Hypabyssal sill & Black colour, fine to medium grain \\
\hline 6 & Adim & AD-1 & Santonian & Sill & Black colour, fine to medium grain \\
\hline 7 & & AD-2 & Santonian & Hypabyssal sills & Black colour, fine to medium grain \\
\hline 8 & Agwagune & AG-1 & NA & Sill & $\begin{array}{l}\text { Black colour with few grey colour, fine to } \\
\text { medium grain }\end{array}$ \\
\hline 9 & & AG-2 & NA & Sill & $\begin{array}{l}\text { Black colour with few grey colour, fine to } \\
\text { medium grain }\end{array}$ \\
\hline 10 & Agoi Ibami & AI & NA & Dyke & Black colour, fine to medium grain \\
\hline 11 & Ohana & $\mathrm{OH}-1$ & NA & Sill & Black colour, fine to medium grain \\
\hline 12 & & $\mathrm{OH}-2$ & NA & Sill & Black colour, fine to medium grain \\
\hline 13 & Mkpani & MK-1 & Santonian & Sill & Black colour fine to medium grain \\
\hline 14 & & $\mathrm{MK}-2$ & Santonian & Sill & Black colour fine to medium grain \\
\hline 15 & Usumutong & US-1 & NA & Dyke & Black colour, fine to medium grain \\
\hline 16 & & US-2 & NA & Dyke & Black colour, fine to medium grain \\
\hline 17 & Obubra & OB-1 & NA & Sill & $\begin{array}{l}\text { Grey to dark grey with some black colour, } \\
\text { fine to medium grain }\end{array}$ \\
\hline 18 & & OB-2 & NA & Sill & $\begin{array}{l}\text { Grey to dark grey with some black clolour, } \\
\text { fine to medium grain }\end{array}$ \\
\hline 19 & Ugep & UG-3 & Santonian & Sill & Black colour, fine to medium grain \\
\hline 20 & & UG-4 & Santonian & Sill & Black colour, fine to medium grain \\
\hline 21 & Okorotong & OK-1 & Early Cretaceous & Sill & Dark grey, medium grain \\
\hline 22 & & OK-2 & Early Cretaceous & Sill & Dark grey, medium grain \\
\hline 23 & Otugwang & OT-1 & Early Cretaceous & Sill & Dark ash, medium grain \\
\hline 24 & & OT-2 & Early Cretaceous & Sill & Dark ash,, medium grain \\
\hline 25 & Bedia & B-1 & Early Cretaceous & Sill & Black colour, medium grain \\
\hline 26 & & B-2 & Early Cretaceous & Sill & Black colour, medium grain \\
\hline 27 & Okorshie & OKO-1 & Early Cretaceous & Sill & Grey colour, medium grain \\
\hline 28 & & OKO-2 & Early Cretaceous & Sill & Grey colour, medium grain \\
\hline 29 & Amunga & AM-1 & Early Cretaceous & Sill & Dark grey colour, medium grain \\
\hline 30 & & $\mathrm{AM}-2$ & Early Cretaceous & Sill & Dark grey colour, medium grain \\
\hline
\end{tabular}

NA- Not available.

Ikom- Mamfe embayment - 1-9, 11-20; Oban Massif-10; Obudu plateau -21-30.

Dolerite from the Obudu plateau were collected at Okorotong (OK), Otugwang (OT), Bedia (B), Okorshie (OKO) and Amunga (AM), where they occur as sills and are closely associated with amphibolites. They constitute the mafic rocks in the area.

The tests carried out on the samples are; uniaxial compressive strength, Schmidt hammer test, water absorption, density, porosity, specific gravity and durability index (Table 2).

\section{Results}

Table 2 details the results of various physical and mechanical parameters that were determined in all the dolerite samples obtained from the study areas. 
Table 2. Result of mechanical and physical properties of dolerite samples

\begin{tabular}{|c|c|c|c|c|c|c|c|c|}
\hline $\mathrm{S} / \mathrm{N}$ & LCOATION & $\begin{array}{l}\text { DENSITY } \\
\left(\mathrm{g} / \mathrm{cm}^{3}\right)\end{array}$ & $\begin{array}{l}\text { SPECIFIC } \\
\text { GRAVITY }\end{array}$ & $\begin{array}{c}\text { POROSITY } \\
(\%)\end{array}$ & $\begin{array}{l}\text { DURABILITY } \\
\text { INDEX (\%) }\end{array}$ & $\begin{array}{c}\text { WATER } \\
\text { ABSORPTION } \\
(\%)\end{array}$ & $\begin{array}{l}\text { SCHMIDT HAMMER } \\
\left(\mathrm{N} / \mathrm{mm}^{2}\right)\end{array}$ & $\begin{array}{c}\text { UNIAXIAL } \\
\text { STRENGTH } \\
\left(\mathrm{N} / \mathrm{mm}^{2}\right)\end{array}$ \\
\hline 1 & Ugep (UG-1) & 2.73 & 2.89 & 0.55 & 97.83 & 0.65 & 45.33 & - \\
\hline 2 & Ugep (UG-2) & 2.73 & 2.75 & 0.61 & 97.56 & 0.76 & 31.17 & - \\
\hline 3 & Ekori (E-1) & 2.74 & 2.75 & 0.57 & 97.17 & 0.78 & 43.63 & - \\
\hline 4 & Ekori (E-2) & 2.76 & 2.75 & 0.58 & 98.04 & 0.78 & 40.52 & - \\
\hline 5 & Ekori (E-3) & 2.83 & 2.89 & 0.54 & 98.42 & 0.75 & 34.57 & - \\
\hline 6 & $\operatorname{Adim}(\mathrm{AD}-1)$ & 2.99 & 2.89 & 0.44 & 97.72 & 0.47 & 43.24 & - \\
\hline 7 & $\operatorname{Adim}(\mathrm{AD}-2)$ & 2.89 & 2.89 & 0.43 & 97.82 & 0.37 & 39.38 & - \\
\hline 8 & Agwagune (AG-1) & 2.69 & 2.75 & 1.1 & 97.05 & 0.9 & 45.9 & - \\
\hline 9 & Agwagune (AG-2) & 2.67 & 2.75 & 1.19 & 96.68 & 0.99 & 43.35 & - \\
\hline 10 & Agoi-Ibami (AI) & 3.07 & 3 & 0.34 & 99.21 & 0.26 & 40.88 & - \\
\hline 11 & Ohana (OH-1) & 2.72 & 2.88 & 1.3 & 98.36 & 0.58 & 48.3 & 50.8 \\
\hline 12 & Ohana (OH-2) & 2.8 & 2.8 & 1.11 & 98.48 & 0.55 & 48.5 & 51.2 \\
\hline 13 & Mkpani (MK-1) & 2.65 & 2.8 & 1.4 & 97.78 & 0.71 & 48 & 51.6 \\
\hline 14 & Mkpani (MK-2) & 2.69 & 2.88 & 1.43 & 97.83 & 0.74 & 48.17 & 51.8 \\
\hline 15 & Usumutong(US-1) & 2.71 & 2.89 & 1.33 & 97.92 & 0.67 & 48.33 & 50.8 \\
\hline 16 & Usumutong(US-2) & 2.7 & 2.89 & 1.35 & 97.81 & 0.68 & 48.23 & 51.2 \\
\hline 17 & Obubra (OB-1) & 2.79 & 2.89 & 0.95 & 98.37 & 0.54 & 49.83 & 51.4 \\
\hline 18 & Obubra (OB-2) & 2.81 & 2.89 & 0.9 & 98.81 & 0.53 & 49.67 & 51.6 \\
\hline 19 & Ugep (UG-3) & 2.43 & 2.75 & 4.55 & 97.3 & 1.59 & 33.67 & 36.8 \\
\hline 20 & Ugep (UG-4) & 2.47 & 2.7 & 4.35 & 97.71 & 1.2 & 35.67 & 35.2 \\
\hline 21 & Okorotong (OK-1) & 2.88 & 2.88 & 1.11 & 98.07 & 0.28 & 49.5 & 46 \\
\hline 22 & Okorotong (OK-2) & 2.85 & 2.72 & 1.33 & 97.28 & 0.31 & 48.25 & 46.8 \\
\hline 23 & Otugwang (OT-1) & 2.87 & 2.52 & 1.14 & 97.58 & 0.34 & 49 & 55.2 \\
\hline 24 & Otugwang (OT-2) & 2.99 & 2.95 & 0.5 & 98.54 & 0.14 & 45.5 & 54 \\
\hline 25 & Bedia (B-1) & 2.96 & 2.88 & 0.73 & 98.23 & 0.2 & 51 & 56 \\
\hline 26 & Bedia (B-2) & 2.93 & 2.94 & 0.71 & 97.63 & 0.23 & 45.25 & 52.3 \\
\hline 27 & Okorshie(OKO-1) & 2.79 & 2.82 & 1.48 & 97.08 & 0.42 & 48.5 & 44.8 \\
\hline 28 & Okorshie(OKO-2) & 2.73 & 2.46 & 1.88 & 96.9 & 0.5 & 52 & 42 \\
\hline 29 & Amunga (AM-1) & 2.88 & 2.77 & 1.29 & 97.03 & 0.27 & 50.75 & 44 \\
\hline \multirow[t]{2}{*}{30} & Amunga (AM-2) & 2.97 & 2.98 & 0.7 & 98.23 & 0.17 & 49.5 & 52 \\
\hline & Average & 2.79 & 2.82 & 1.19 & 97.81 & 0.58 & 45.19 & 48.78 \\
\hline
\end{tabular}

The uniaxial compressive strength was obtained by trimming the samples into $50 \mathrm{~mm}$ by $50 \mathrm{~mm}$ sizes and continuously loading them until failure, this was done using the Universal Testing Machine (UTM). The Schmidt hammer test was carried out in accordance with the standard operating instruction given by Schmidt (1972) using the Type N Schmidt hammer. Specific gravity tests were done using the density bottle method $\left(50 \mathrm{~cm}^{3}\right)$, the soaking method was applied in determining water absorption, porosity was determined using the boiling and cooling method while durability was done using the slake drum method. Density tests were carried out using the Eureka can and these as well as the specific gravity tests were done with distilled water. The basic mineralogy of all the samples was estimated using thin section analyses.

\subsection{Mineralogy}

The petrographic analyses of 30 samples of dolerite in Cross River State (DCRS) showed that they contain $40-60 \%$ of plagioclase (anorthite-albite) and $20-40 \%$ of pyroxene (usually augite but sometimes hypersthene or diopside). The accessory minerals are apatite, Iron minerals (ilmenite, magnetite or pyrite) which compose about $10 \%$ of the rock, olivine and quartz are rare while chlorite occurs as a negligible amount $(<1 \%)$.

Petrographic studies of the various rock samples show that the mineralogy of dolerite samples from Obudu 
plateau is quite similar to those of the Oban massif but slightly different from samples from the Ikom-Mamfe embayment. There is more plagioclase in the dolerite of the Obudu plateau and Oban massif (45-55\%) than those of the Ikom-Mamfe embayment (40-50\%) while more proxenes are found in the dolerite from the Ikom-Mamfe embayment (30-40\%) than those from the Obudu plateau and Oban massif (20-30\%). Quartz is seemingly absent in the dolerites of Obudu plateau and Oban massif, while olivine was not found in the dolerites of Ikom-Mamfe embayment. This mineralogy justifies the colour of these dolerites.

Detailed geochemical analysis carried out by Hossain (1981) on the dolerite of Ikom-Mamfe embayment and Ekwueme (1994) on the dolerites of Obudu plateau shows that a more tholeiitic magma formed the dolerite of Ikom-Mamfe embayment hence their black colour.

\subsection{Physical and Mechanical Properties}

The DCRS are generally fine-medium grained, grey to dark ash with some black coloured variety. The medium grained variety is more abundant on top of the hills while the fine-grained dolerites occur mostly along fractures and fault zones.

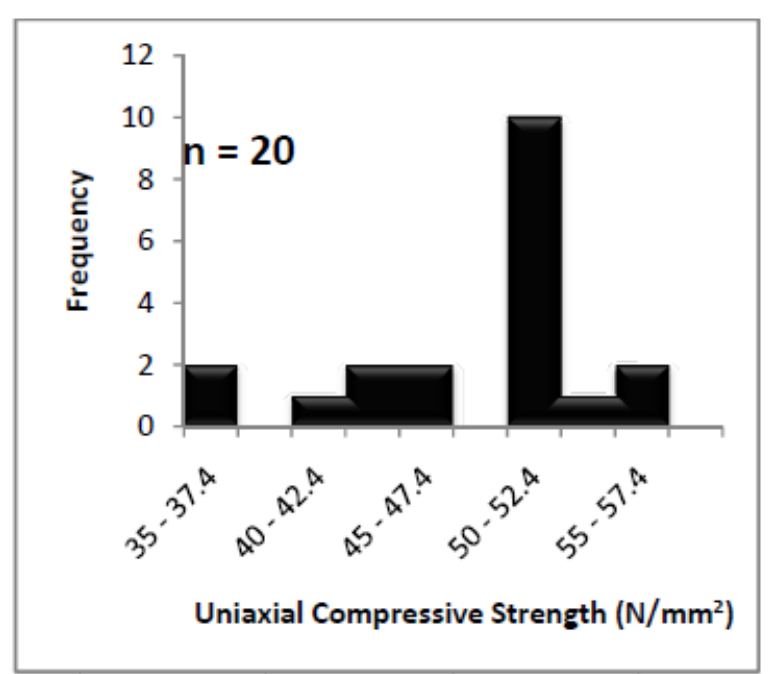

Figure 3. Histogram of uniaxial compressive strength

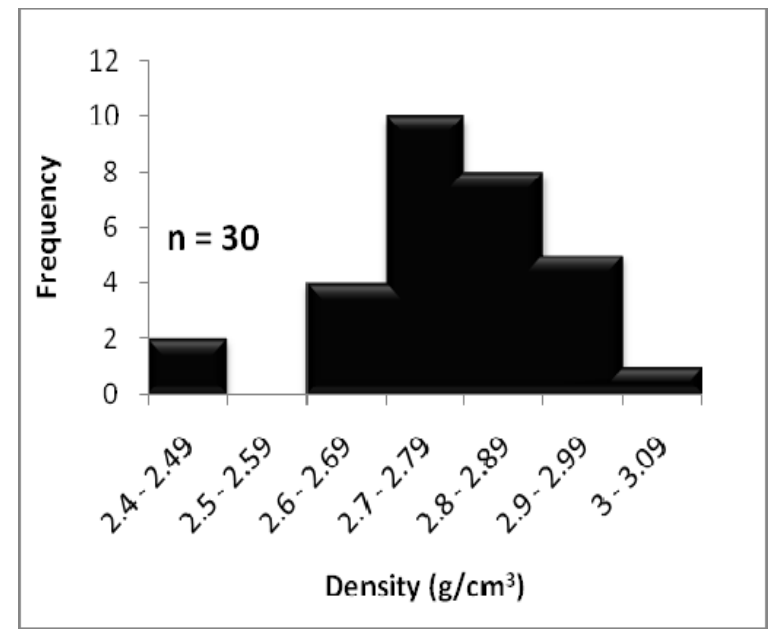

Figure 5. Histogram of density

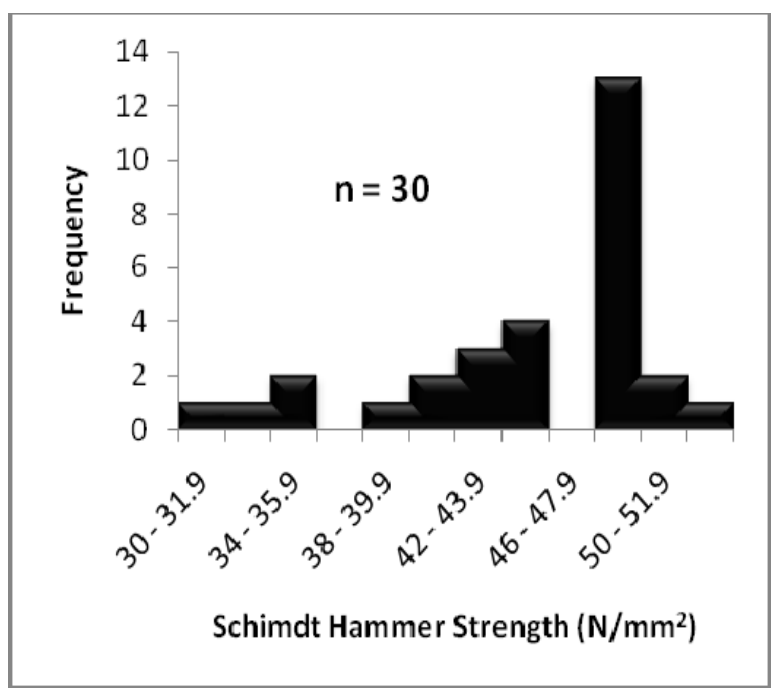

Figure 4. Histogram of Schmidt hammer strength

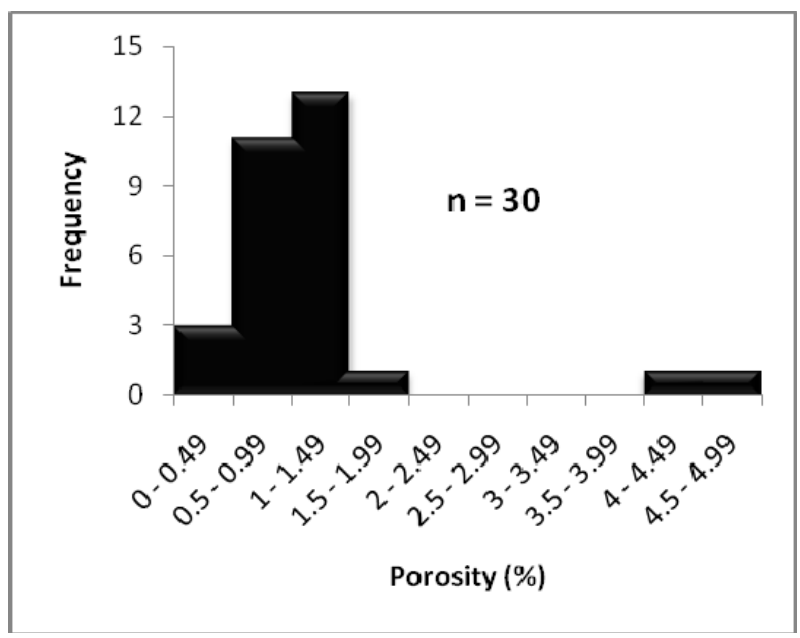

Figure 6. Histogram of porosity

Data from test results (Table 2) show that the uniaxial compressive strength value of DCRS ranges between 34.2 $\mathrm{N} / \mathrm{mm}^{2}$ and $56 \mathrm{~N} / \mathrm{mm}^{2}$ with a mean value of $48.7 \mathrm{~N} / \mathrm{mm}^{2}$, while the modal occurrence is between $50.0 \mathrm{~N} / \mathrm{mm}^{2}$ and $52.0 \mathrm{~N} / \mathrm{mm}^{2}$ (Figure 3). The Schmidt hammer values also vary widely from $31.17 \mathrm{~N} / \mathrm{mm}^{2}$ to $51.00 \mathrm{~N} / \mathrm{mm}^{2}$ with an average value of $45.19 \mathrm{~N} / \mathrm{mm}^{2}$. About $40 \%$ of the DCRS samples have Schmidt hammer strength values 
between $48.00 \mathrm{~N} / \mathrm{mm}^{2}$ and $50.00 \mathrm{~N} / \mathrm{mm}^{2}$ (Figure 4). The densities of the dolerites vary narrowly $\left(2.43 \mathrm{~g} / \mathrm{cm}^{3}\right.$ $3.07 \mathrm{~g} / \mathrm{cm}^{3}$ ) with $90 \%$ of the values ranging between $2.5 \mathrm{~g} / \mathrm{cm}^{3}$ and $2.9 \mathrm{~g} / \mathrm{cm}^{3}$ (Figure 5) and an average of 2.79 $\mathrm{g} / \mathrm{cm}^{3}$. Porosity values range very widely between $0.34 \%$ and $4.55 \%$ (Figure 6 ) with a mean porosity value of 1.19. Similar to the density values, the specific gravity values also vary narrowly from 2.46 to 3 with an average value of 2.82, though most of the samples had values between 2.7 and 2.9 (Figure 7). The water absorption values of the DCRS ranges between $0.14 \%$ and $1.59 \%$ with an average of $0.05 \%$ and a preponderance of values between $0.14 \%$ and $0.8 \%$ (Figure 8 ). The durability values range between $96.9 \%$ and $99.21 \%$ with an average of 97.8\% (Figure 9).

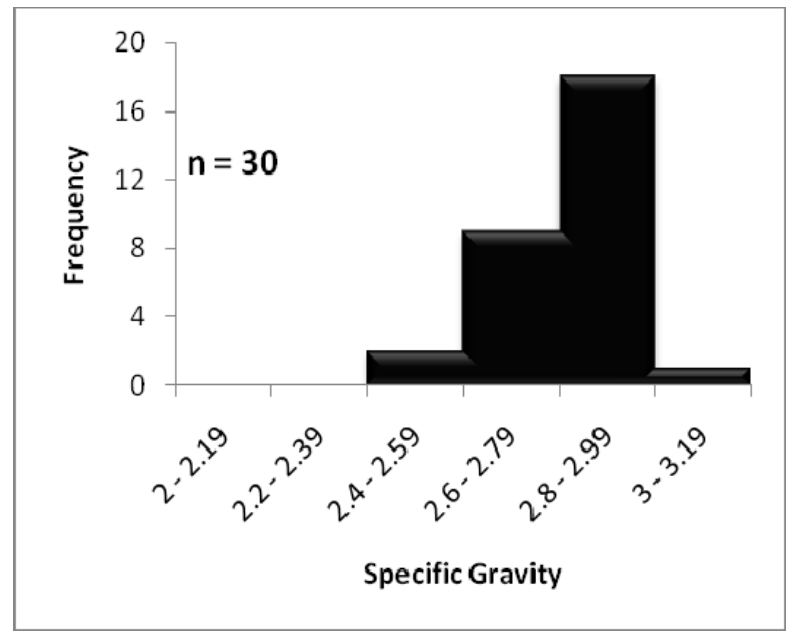

Figure 7. Histogram of specific gravity

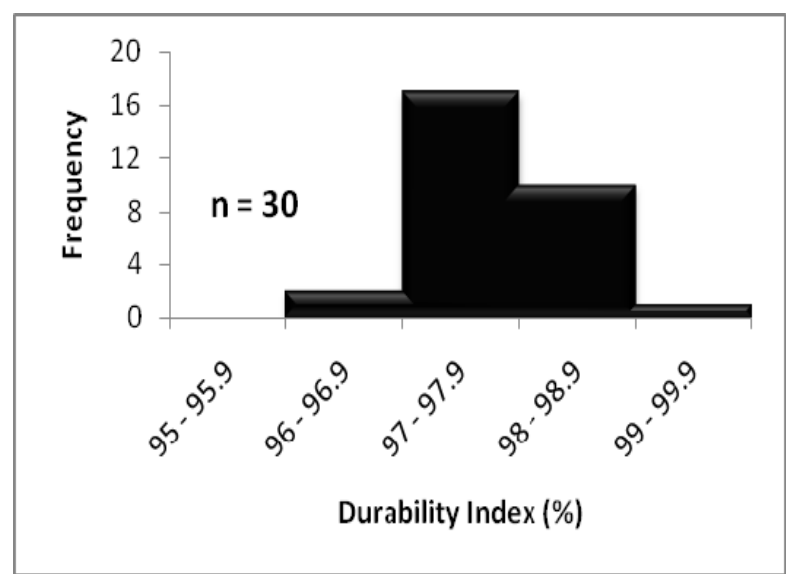

Figure 9. Histogram of durability index

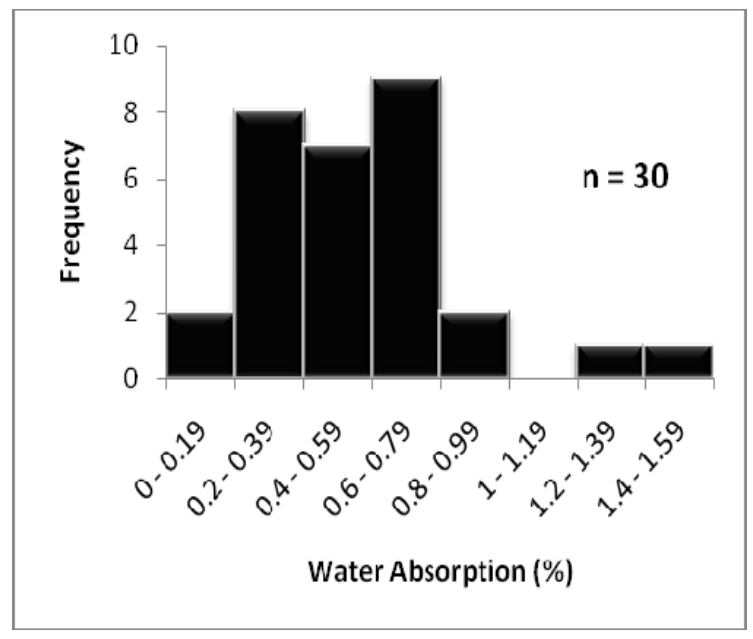

Figure 8 . Histogram of water absorption

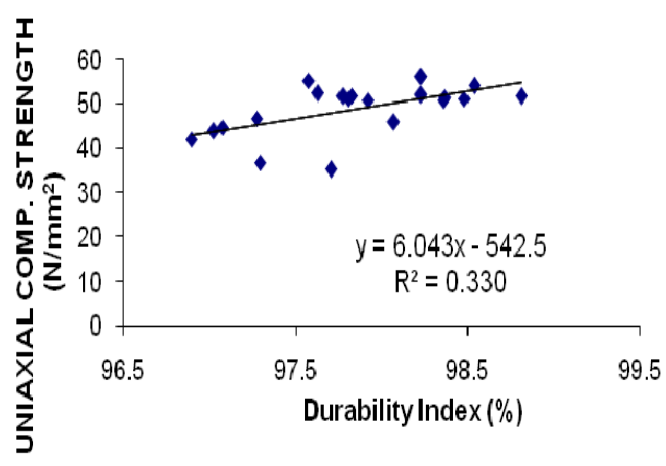

Figure 10. Uniaxial compressive strength vs durability index

\subsection{Graphs of Index Properties}

Some of the index properties produced a good linear graph (Figures 10, 13 and 14) which are quite interesting and lend some credence to the test results. Others produce near linear graphs which are not exponential or polynomial. There is definite positive correlation between uniaxial compressive strength and durability index, density and specific gravity, water absorption and porosity, durability and density, Schmidt hammer rebound strength and uniaxial compressive strength, uniaxial compressive strength and density (Figures 10, 11, 12, 15, 16 and 17). Negative correlation exists, on the other hand, between density and porosity, as well as uniaxial strength and porosity (Figures 14 and 13) in this unfoliated igneous rock type. The generally low porosity feeds into the strength, density and low water absorption. 


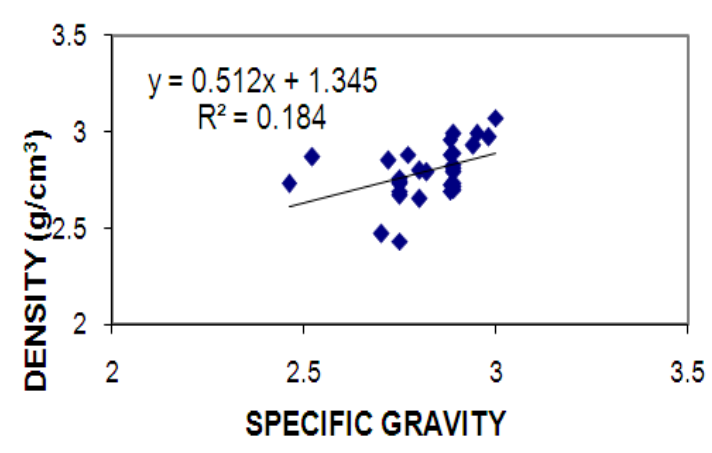

Figure 11. Density vs specific gravity

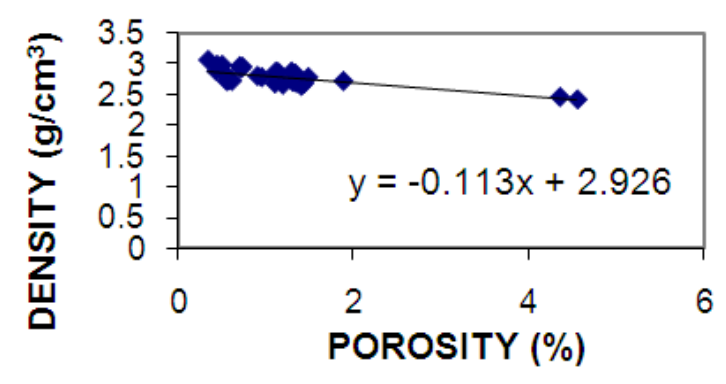

Figure 13. Density vs porosity

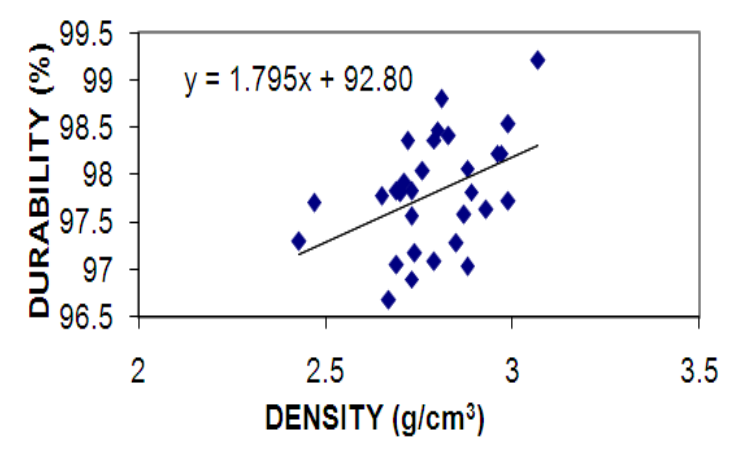

Figure 15. Durability vs density

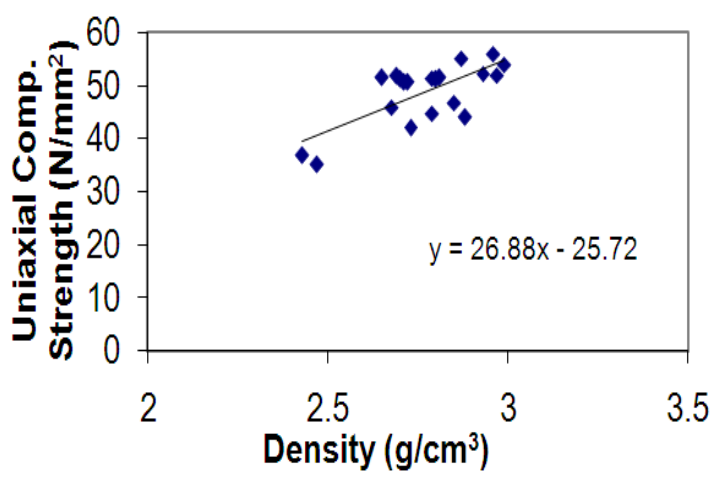

Figure 17. Uniaxial compressive strength vs density

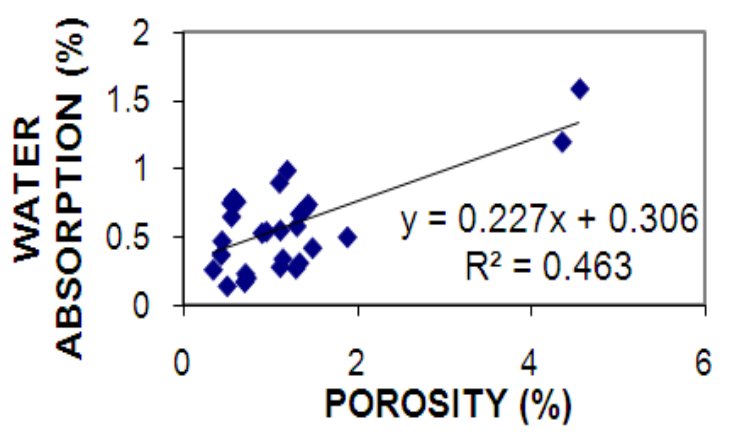

Figure 12. Water absorption vs porosity

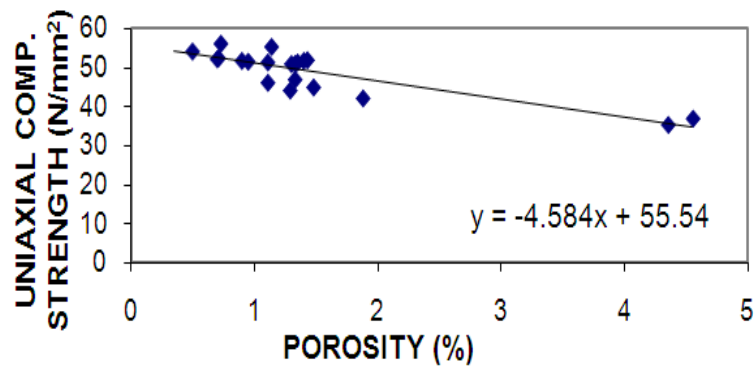

Figure 14. Uniaxial compressive strength vs porosity

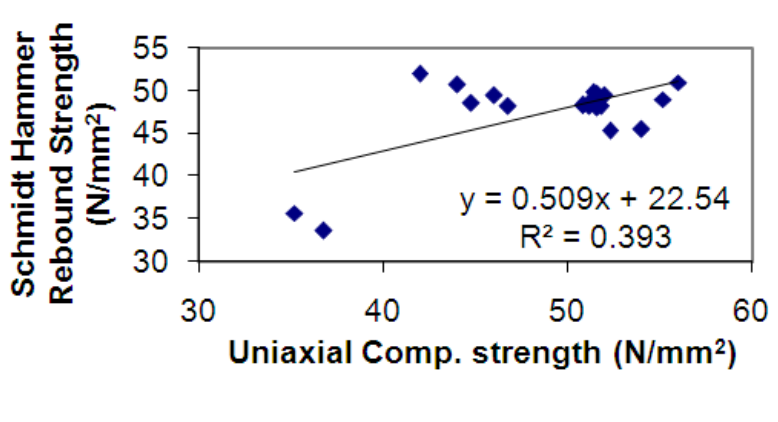

Figure 16. Schmidt hammer strength vs uniaxial compressive strength

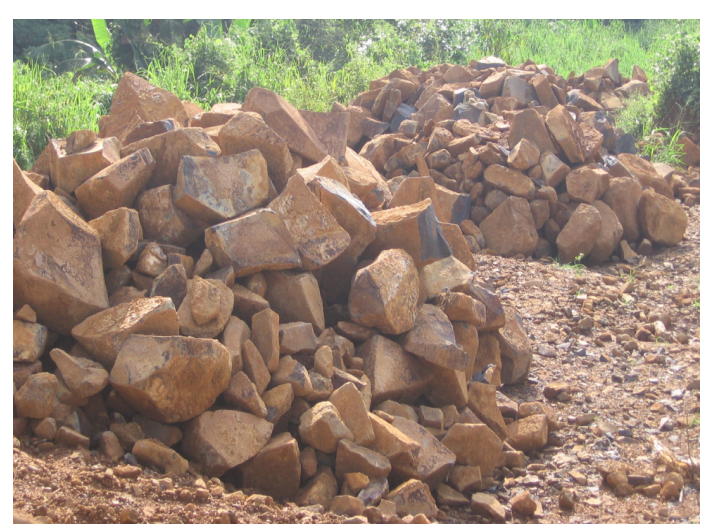

Figure 18. Local quarrying of dolerite in Okorshie (Southeastern Nigeria) 
The durability of the DCRS is seen to increase as the compressive strength of the rocks increases (Figure 10). The majority of the samples from the study area fall within UCS values of $50-52 \mathrm{~N} / \mathrm{mm}^{2}$ (Figure 3) and durability index values of 97.5-98.5\% (Figure 9). This is acceptable for construction stones (Deere and Miller, 1966). Most of the DCRS show high density and specific gravity values as they cluster within $2.7-3.0 \mathrm{gcm}^{-3}$ and 2.8-3.0 respectively (Figures 5, 7 and 11) this is good for construction stones (Leaman, 1972). The water absorption against porosity graph (Figure 12) indicates that the DCRS have low porosity, hence a low water absorption capacity. This is equally favorable for construction purposes as high porosity and high water absorption capacity would likely cause swelling and hydrolytic weakening of the rock, which is bad for construction purposes. High compaction of mineral crystals, which results in low porosity and high density (Figure 13) of rocks as exemplified by the DCRS is a desired characteristic for construction stones. Similarly, the uniaxial compressive strength of the DCRS, which is related to porosity (Esu et al., 1994), is high due to their low porosity (Figure 14) and good for construction purpose. The durability of a construction material/stone is linked to its density so that high density materials tend to have high durability. The situation is not different for the DCRS (Figure 15). Figures 16 and 17 show that the DCRS have ability to withstand high load impact for a reasonably long period of time which is good for construction purposes.

\section{Discussion}

Plagioclase and pyroxene are the essential minerals in the DCRS. These minerals have been known to sometimes alter into chlorite and clays (Leaman, 1972), which may cause swelling when wet and shrinking when dry. Despite that, the DCRS have high durability (Table 2, Figure 9) and they are in a relatively unweathered to slightly weathered condition, which is inferred from the observation that deep red soil or travertine (evidence of weathering) was only found in the first few layers $(<2 \mathrm{~m}$ thick) of some sill. Nevertheless, these slightly weathered dolerites can still be used as base and sub-base in road construction if properly applied (Kleyn \& Bergh, 2008).

The DCRS generally are fine-medium grained in texture, free from soft patches and cracks, making them good construction/dimension stone materials. Generally, the average density of dolerites is between $2.7 \mathrm{~g} / \mathrm{cm}^{3}$ to 3.2 $\mathrm{g} / \mathrm{cm}^{3}$ (Leaman, 1972). Comparing this with the DCRS average of $\left(2.79 \mathrm{~g} / \mathrm{cm}^{3}\right)$, it can be said that the DCRS is dense enough for construction purpose. The average porosity of the DCRS (1.19\%) is equivalent to that expected from an average dolerite 1\% (Leaman 1972), and this indicates that the DCRS can adequately serve as a construction stone. The wide porosity distribution range is probably due to the fact that some intrusive are more exposed than others i.e some has overburden less than $1 \mathrm{~m}$ (Figure 1) while others are up to $2 \mathrm{~m}$ or more thus the weathered state conditions of all the samples are not exactly the same. This probably had more effect on porosity than other index properties. The average specific gravity value of the DCRS (2.82), which is higher than the expected average (2.5) (Leaman, 1972), gives the DCRS a place as a construction stone. Water absorption values are not expected to exceed 5\% for construction materials and based on Amah et al. (2012) classification, all samples has water absorption in class A (less than 2) which is most suitable for all civil construction works. The DCRS have water absorption values far below this $(0.57 \%)$, and hence can serve as a good material for floor tiling. In terms of durability, which is generally based on the rock's natural physical properties and mechanical characteristics, the DCRS can be classified as medium high to high (Johnson \& Degraff, 1988). This indicates that the DCRS can be used with confidence as a construction stone. Also based on the Deere and Miller (1966) classification of intact rocks on the basis of strength, a majority of the DCRS are of medium strength, while the site investigation code of practice (Cp 2001) classifies the dolerite as strong.

\section{Conclusions}

The dolerites of Cross River State exhibit satisfactory physical and mechanical properties with acceptable mineralogy. A medium/strong compressive strength, low porosity and water absorption, average density and specific gravity and high durability make it suitable for construction purposes. These rocks are already being locally quarried and used in construction (Figure 18). The anomalously low density, Schmidt hammer, and uniaxial compressive strength values as well as high water absorption and porosity value in some of the samples (UG-3 and UG-4) can be attributed to the effect of weathering and retrograde metamorphism as these samples were collected from the top of the sill. Mineralogically, UG-3 and UG-4 have more chlorite than all the other samples. So for better results and more competent rock, it is advised that sampling be done below 2 meters from the surface. The DCRS unless properly treated/stabilized should not be used for heavy traffic construction but can be readily applied in concrete for light foundation loads and buildings.

However the environmental conditions within which it would be used should be properly evaluated before its application and due to the weathering pattern of dolerites (i.e. from top to bottom or from sides inwards), the first 
few meters around a dolerite sill or dyke should be avoided when quarrying for construction stones.

\section{Acknowledgement}

The authors appreciate Ogba D. A., Ajah E. E. and Ekere I. I. who assisted during the field work exercise. Mr Igonor E. E. is appreciated for his assistance with preparation of figures.

\section{References}

Amah, E. A., Esu, E. O., Oden, M. I., \& Anam, G. (2012). Evaluation of Old Netim basement rocks (south-eastern Nigeria) for construction aggregates. Journal of Geography and Geology, 4(3), 90-98. http//dx.doi.org/10.5539/jgg.v4n3p90

Deere, D. U., \& Miller, R. P. (1966). Engineering classification and index properties of intact rock.Tech report. Air Force Weapons Laboratory., New Mexico, No AFWL-TR-65-116.

Ekwueme, B. N. (1994). Basaltic magmatism related to the early stages of rifting along the Benue trough through the Obudu dolerites of southeastern Nigeria. Geol. J., 29, 269-276. $\mathrm{http} / / \mathrm{dx}$.doi.org/10.1002/gj.3350290306

Ephraim, B. E. (2012). Granitoids of older granite suites in southeastern Nigeria. Advances in Applied Science Research, 3(2), 994-1007.

Esu, E. O., Edet, A. E., Teme, S. C., \& Okereke, C. S. (1994). A study of some Nigerian carbonate rocks for the building construction industry. Eng. Geol., 37, 271-283. http//dx.doi.org/10.1016/0013-7952(94)90061-2

Fairhead, J. D., Okereke, C. S., \& Nnange J. M. (1991). Crustal structure of the Mamfe basin, West Afric based on gravity data. Tectonophysics, 183, 351-358. http//dx.doi.org/10.1016/0040-195191)90368-3

Hossain, M. T. (1981). Geochemistry and petrology of the minor intrusives between Efut Eso and Nko in the Ugep area of Cross River State. Nigeria. J. Min. Geol., 18(1), 42-51.

Johnson, R. B., \& DeGraff, J. V. (1988). Principles of Engineering Geology. (p. 497) Wiley New York.

Kleyn, E. G., \& Bergh, A. O. (2008). Some practical aspects regarding the handling of dolerite for base and sub-base construction. 27 $7^{\text {th }}$ Southern African Transport Conference (SATC), 98-107.

Leaman, D. E. (1972). The Engineering properties of Tasmanian dolerite with particular reference to the route of the Bell Bay railway. Tech. Rep. Mines, 16, 148-163.

Oden, M. I., Okpamu, T. A., \& Amah, E. A. (2012). Comparative analysis of fracture lineaments in Oban and Obudu areas, SE Nigeria. Journal of Geography and Geology, 4(2), 36-47. http//dx.doi.org/10.5539/jgg.v4n2p36

Schmidt, E. (1972). Operating instructions: Concrete test hammer N. Consulting Engineer, Bachlettenstrasse, 52, CH-400. Basle, Switzerland. 